\title{
THE ROLE OF UREA IN THE URINE CONCENTRATING MECHANISM
}

\author{
BY NORMAN G. LEVINSKY AND ROBERT W. BERLINER WITH THE TECH NICAL \\ ASSISTANCE OF AGNES S. PRESTON \\ (From the Laboratory of Kidney and Electrolyte Metabolism, National Heart Institute, \\ Bethesda, Md.)
}

(Submitted for publication October 10, 1958; accepted January 2, 1959)

Many years ago, Gamble, McKhann, Butler and Tuthill (1) described "an economy of water in renal function referable to urea." Recently, experiments in the rat (2-4) and man (5) have confirmed their suggestion that the urine volume required to excrete a given solute load is reduced when urea is a principal urinary solute. An hypothesis assigning a unique role to urea in the urine concentrating process has been presented in the preceding paper (6) and elsewhere (7). In this paper, it is demonstrated that urine concentrating ability is reduced in dogs on a low protein diet, and that this defect is reversed acutely when urea is given. A similar acute effect of urea is also shown to occur in man. The data support the hypothesis that the passive accumulation of urea in the medullary interstitial fluid accounts for its ability to enhance urine concentration.

\section{METHODS}

Studies were done on five female mongrel dogs, each 14 to $18 \mathrm{Kg}$. in weight. The dogs were fed a synthetic diet which supplied approximately 80 cal. per $\mathrm{Kg}$. per day. During the control period, the diet contained about $50 \mathrm{Gm}$. per day of protein. During the "low protein" period the diet was protein-free, except that $100 \mathrm{mg}$. per day of egg albumin was added to the diet when this period was more than 10 days long.

Studies on dogs were done after 42 hours of dehydration. Twenty-four and 16 hours prior to testing, 5 units of a long-acting vasopressin preparation (Pitressin Tannate in oil) was administered intramuscularly. A 24 hour urine collection was usually made during the last day of the dehydration period. For tests of urine concentrating ability, an infusion containing $50 \mathrm{mU}$ per $\mathrm{Kg}$. per hour of vasopressin, inulin and $p$-aminohippurate $(\mathrm{PAH})$ in water was given at about $0.2 \mathrm{ml}$. per minute. Several collection periods were obtained to serve as a measure of maximum urine osmolality. An additional infusion of 6.5 per cent mannitol in water or 3 per cent urea in 0.9 per cent saline was then given at several rates, to permit three or four collection periods at stable urine flows to be obtained at each of several levels of solute excretion in the range from 600 to 6,000 $\mu$ Osm. per minute. When the acute effects of urea on urine concentration were to be studied, only the first infusion was given. After several control periods, the urea, dissolved in 10 to $20 \mathrm{ml}$. of water, was given by stomach tube.

The dogs were standing, partially supported by slings, during clearance periods. An indwelling catheter was used, and the bladder was emptied with the aid of abdominal compression and air washouts. Inulin clearance was used as a measure of glomerular filtration rate (GFR) and PAH clearance as a measure of effective renal blood flow. The analytical methods used have been listed elsewhere $(6,8)$.

Kidney tissue for analysis was obtained from dogs dehydrated for 42 hours, as described above. The methods involved in tissue analysis are described in the preceding paper (6).

The acute effects of urea on urine concentration were also studied in three young male human volunteers. The urine concentration test was conducted as follows. After 21 hours of water deprivation, the subjects voided each hour for 7 to 10 hours. After several collections with stable urine osmolality had been obtained, the urea, dissolved in 30 to $50 \mathrm{ml}$. of water, was taken by mouth. This test was performed after the subjects had been on a diet containing $20 \mathrm{Gm}$. per day of protein for 6 to 10 days.

\section{RESULTS}

\section{Effect of low protein diet on urine concentration in dogs}

In Table I, the changes in urine volume and solute concentration in one dog on a low protein diet are shown. Each 24 hour collection was begun after 18 hours of dehydration ; long-acting vasopressin was given twice during the collection period. After one week on the low protein diet, urine concentration had fallen to about one-half the control value. At this time, solute excretion was still approximately at control levels. Thereafter, urine concentration remained relatively stable, while solute excretion fell to about onehalf the control value on the nineteenth and twenty-sixth days of the low protein diet. Thus, 
TABLE I

Twenty-four hour urine solute concentrations in dog on low protein diet

\begin{tabular}{|c|c|c|c|c|c|c|}
\hline & Volume & $\begin{array}{c}\text { Urine } \\
\text { osmolality }\end{array}$ & $\begin{array}{c}\text { Urea } \\
\text { conc'n }\end{array}$ & $\begin{array}{l}\text { Sodium } \\
\text { conc'n }\end{array}$ & $\begin{array}{l}\text { Potassium } \\
\text { conc'n }\end{array}$ & $\begin{array}{c}\text { Plasma } \\
\text { urea }\end{array}$ \\
\hline $\begin{array}{l}\text { Control } \\
7 \text { th day } \\
13 \text { th day } \\
19 \text { th day } \\
26 \text { th day }\end{array}$ & $\begin{array}{l}m l . \\
170 \\
365 \\
310 \\
183 \\
180\end{array}$ & $\begin{array}{c}\text { mOsm./Kg. } \mathrm{H}_{2} \mathrm{O} \\
1,609 \\
869 \\
851 \\
848 \\
893\end{array}$ & $\begin{array}{c}m M / L . \\
752 \\
111 \\
112 \\
55 \\
97\end{array}$ & $\begin{array}{c}m E q . / L . \\
226 \\
286 \\
283 \\
301 \\
97\end{array}$ & $\begin{array}{c}m E q . / L \\
71 \\
85 \\
122 \\
124 \\
199\end{array}$ & $\begin{array}{c}m M / L . \\
5.5 \\
2.6 \\
2.7 \\
2.3 \\
2.6\end{array}$ \\
\hline
\end{tabular}

urine concentration was reduced both at control and at decreased levels of solute excretion. Urine urea concentration had fallen sharply by the seventh day on low protein and remained stable thereafter. The decrease in urea concentration accounts for about 85 to 95 per cent of the fall in urine osmolality. Plasma urea fell to one-half the control value during the first week on the low protein diet and was roughly constant thereafter. The GFR was $77 \mathrm{ml}$. per minute on the control day, and $55 \mathrm{ml}$. per minute on the seventh day of low protein diet.

Figure 1 [fashioned after the comparable figure in man of Epstein, Kleeman, Pursel and Hendrikx (5)] shows the changes in maximum concentration after six to eight days on the low protein diet in the five dogs studied. Maximum urine osmolality had fallen uniformly to about one-half the control values. Thereafter, maximum urine osmolality either remained relatively constant (two dogs) or gradually decreased to slightly lower levels (three dogs) as the low protein diet was prolonged. The minimum value in the latter dogs after three to four weeks on the diet was about one-third of the control value. In all the dogs, the fall in urine urea concentration accounted for about 80 to 95 per cent of the fall in urine osmolality. The changes in plasma urea were in general comparable to those shown in Table I. In one dog, plasma urea fell sharply to less than $0.5 \mu \mathrm{M}$ per ml. after three weeks on the low protein diet.

The glomerular filtration rate had fallen about 25 per cent by the sixth to eighth day on the low protein diet in four of the five dogs studied (77 to 48 ml. per minute; 77 to $55 ; 75$ to $65 ; 90$ to 71 ). In one dog, the filtration rate did not change during two weeks on the diet ( $55 \mathrm{ml}$. per minute). These figures represent the average of the three to four consecutive periods during mannitol diuresis in which the negative free-water clearance $\left(\mathrm{T}_{\mathbf{H}_{2} \mathrm{O}} \mathrm{O}\right)$ was highest. This value was used arbitrarily because the filtration rate was often very labile during the course of graded osmotic diuresis, so that an average of all the periods (usually 10 to 15 ) would not be meaningful. For example, in one dog the GFR rose from 68 to $81 \mathrm{ml}$. per minute during graded mannitol diuresis on the control diet; and fell from 67 to $58 \mathrm{ml}$. per minute during a comparable study on the low protein diet. The values during the periods of highest negative free-water clearance were 75 and $65 \mathrm{ml}$. per minute, respectively. In two dogs in which the PAH clearance was measured on the regular and low protein diets, it fell from 290 to 220 , and from 250 to $170 \mathrm{ml}$. per minute, respectively.

The maximum negative free-water clearance fell sharply on the low protein diet, as is shown in

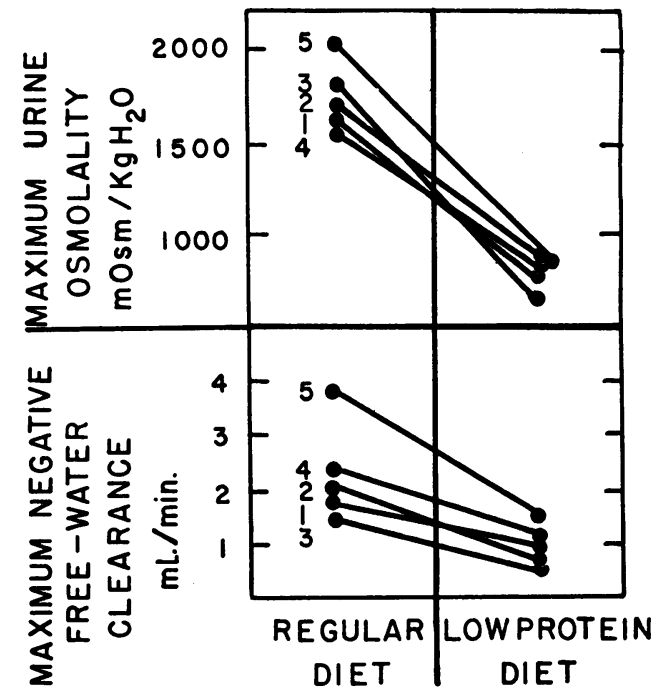

Fig. 1. Maximum Urine Concentration and Maximum Negative Free-Water Clearance in Five Dogs on Regular and Low Protein Diet 
Figure 1. However, certain considerations make the interpretation of changes in $\mathrm{T}^{\mathbf{c}}{ }_{\mathrm{H}_{2} \mathrm{O}}$ in these dogs difficult. The average of the three highest consecutive $\mathrm{T}_{\mathrm{H}_{2} \mathrm{O}}$ values found during graded mannitol diuresis was arbitrarily designated the "maximum" negative free-water clearance. This is not to be equated with the concept of a fixed maximum negative free-water clearance $\left(\mathrm{T}^{\mathrm{c}}{ }_{\mathrm{mH}_{2} \mathrm{O}}\right)$ approached at the highest solute excretions, as postulated by Smith(9). In these and other studies with solute diuresis, we usually did not find even an approximately constant level of $\mathrm{T}^{\mathbf{c}} \mathrm{H}_{2} \mathrm{O}$. Usually, $\mathrm{T}^{\mathrm{c}} \mathrm{H}_{\mathbf{2}} \mathrm{O}$ rose up to a point as solute ex- cretion increased, then began to fall as solute excretion was increased further. The free-water clearance often became positive at the highest levels of solute excretion (i.e., the urine became hypotonic to plasma). During mannitol diuresis on the low protein diet, hypotonic urine was regularly obtained at relatively low solute excretions ( $\mathrm{C}_{\mathrm{osm}}, 10$ to 16 per cent of GFR).

These facts are illustrated in Table II. In the experiment on the regular diet, $\mathrm{T}^{\mathrm{c}}{ }_{\mathrm{H}_{2} \mathrm{O}}$ fell somewhat at the highest rates of solute excretion. In the experiment on the low protein diet, the freewater clearance became positive ( $\mathrm{T}^{\mathrm{c}}{ }_{\mathrm{H}_{2} \mathrm{O}}$ negative)

TABLE II

Solute diuresis *

\begin{tabular}{|c|c|c|c|c|c|c|}
\hline $\begin{array}{l}\text { Urine } \\
\text { flow }\end{array}$ & $\begin{array}{c}\text { Urine } \\
\text { osmolality }\end{array}$ & $\begin{array}{c}\text { Plasma } \\
\text { osmolality }\end{array}$ & Cosm & $\mathrm{T}^{\circ} \mathrm{H}_{2} \mathrm{O}$ & GFR & $\begin{array}{l}\text { Urine } \\
\text { urea }\end{array}$ \\
\hline$m b . / m i n$. & \multicolumn{5}{|c|}{ A. Regular diet } & $\mu M / m l$. \\
\hline $\begin{array}{l}0.32 \\
0.49 \\
0.80 \\
1.53\end{array}$ & $\begin{array}{r}1,192 \\
1,159 \\
937 \\
565\end{array}$ & $\begin{array}{l}306 \\
305\end{array}$ & $\begin{array}{l}1.25 \\
1.87 \\
2.46 \\
2.84\end{array}$ & $\begin{array}{l}0.9 \\
1.4 \\
1.7 \\
1.3\end{array}$ & $\begin{array}{l}57 \\
59\end{array}$ & $\begin{array}{l}478 \\
295\end{array}$ \\
\hline $\begin{array}{l}2.95 \\
3.50 \\
3.25\end{array}$ & $\begin{array}{l}437 \\
438 \\
430\end{array}$ & $\begin{array}{l}305 \\
308\end{array}$ & $\begin{array}{l}4.13 \\
5.02 \\
4.53\end{array}$ & $\begin{array}{l}1.3 \\
1.5 \\
1.3\end{array}$ & $\begin{array}{l}54 \\
62 \\
57\end{array}$ & 72 \\
\hline $\begin{array}{l}4.63 \\
4.64 \\
4.85\end{array}$ & $\begin{array}{l}401 \\
405 \\
406\end{array}$ & $\begin{array}{l}306 \\
311\end{array}$ & $\begin{array}{l}6.06 \\
6.11 \\
6.33\end{array}$ & $\begin{array}{l}1.4 \\
1.5 \\
1.5\end{array}$ & $\begin{array}{l}\mathbf{5 7} \\
55 \\
57\end{array}$ & 48 \\
\hline $\begin{array}{r}9.42 \\
10.30 \\
10.40 \\
10.40\end{array}$ & $\begin{array}{l}362 \\
352 \\
351 \\
353\end{array}$ & $\begin{array}{l}320 \\
324\end{array}$ & $\begin{array}{l}10.70 \\
11.30 \\
11.30 \\
11.40\end{array}$ & $\begin{array}{l}1.2 \\
1.0 \\
0.9 \\
1.0\end{array}$ & $\begin{array}{l}51 \\
51 \\
52 \\
55\end{array}$ & $\begin{array}{l}25 \\
24\end{array}$ \\
\hline \multicolumn{7}{|c|}{ B. Low protein diet } \\
\hline $\begin{array}{l}0.95 \\
1.89 \\
2.74 \\
3.22 \\
3.10\end{array}$ & $\begin{array}{l}555 \\
389 \\
346 \\
327 \\
317\end{array}$ & $\begin{array}{l}293 \\
294\end{array}$ & $\begin{array}{l}1.80 \\
2.51 \\
3.23 \\
3.60 \\
3.35\end{array}$ & $\begin{array}{l}0.9 \\
0.6 \\
0.5 \\
0.4 \\
0.3\end{array}$ & $\begin{array}{l}60 \\
51 \\
55 \\
57 \\
55\end{array}$ & $\begin{array}{r}123 \\
50 \\
64\end{array}$ \\
\hline $\begin{array}{l}4.03 \\
4.13 \\
4.16\end{array}$ & $\begin{array}{l}275 \\
271 \\
270\end{array}$ & $\begin{array}{l}294 \\
294\end{array}$ & $\begin{array}{l}3.74 \\
3.81 \\
3.82\end{array}$ & $\begin{array}{l}-0.3 \\
-0.3 \\
-0.3\end{array}$ & $\begin{array}{l}53 \\
54 \\
53\end{array}$ & 62 \\
\hline $\begin{array}{l}5.63 \\
6.16 \\
6.84\end{array}$ & $\begin{array}{l}271 \\
262 \\
262\end{array}$ & $\begin{array}{l}301 \\
304\end{array}$ & $\begin{array}{l}5.17 \\
5.34 \\
5.89\end{array}$ & $\begin{array}{l}-0.5 \\
-0.8 \\
-1.0\end{array}$ & $\begin{array}{l}52 \\
51 \\
56\end{array}$ & 41 \\
\hline $\begin{array}{l}10.20 \\
12.70 \\
15.60\end{array}$ & $\begin{array}{l}248 \\
245 \\
244\end{array}$ & $\begin{array}{l}305 \\
308\end{array}$ & $\begin{array}{r}8.25 \\
10.10 \\
12.40\end{array}$ & $\begin{array}{l}-2.0 \\
-2.6 \\
-3.3\end{array}$ & $\begin{array}{l}42 \\
48\end{array}$ & $\begin{array}{l}16 \\
13 \\
13\end{array}$ \\
\hline
\end{tabular}

* Infusions: 1) Eight mg. per minute inulin; $4.5 \mathrm{mg}$. per minute PAH ; $100 \mathrm{mU}$ per $\mathrm{Kg}$. per hour vasopressin in water at $0.2 \mathrm{ml}$. per minute. 2) $\mathrm{NaCl}, 20 \mathrm{mM}$ per L.; mannitol, $65 \mathrm{Gm}$. per L. in water at various rates.

In each experiment, the horizontal lines separate a group of periods at a given infusion rate. Periods were 6 to 10 minutes in length and 30 minutes was allowed before starting collections at each rate of infusion. Both experiments were performed on a single dog. 
,TABLE III

Acute effect of urea on urine concentration in dog on low protein diet

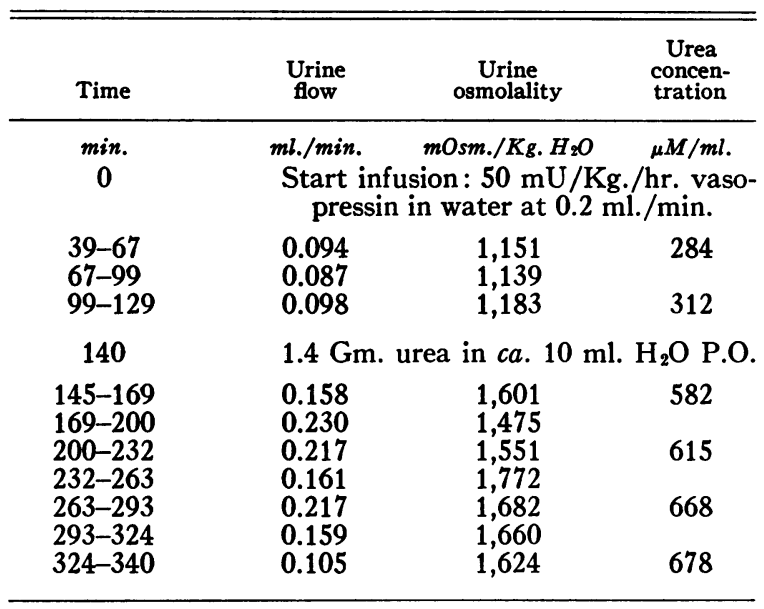

at relatively low levels of solute excretion and the degree of hypotonicity increased as solute excretion was increased. It is emphasized that this dog had been dehydrated for 42 hours prior to each experiment, had received 10 units of long-acting vasopressin in the previous 24 hours and was receiving $100 \mathrm{mU}$ per $\mathrm{Kg}$. per hour of vasopressin intravenously throughout each experiment. In this dog, the GFR was relatively stable between experiments and during each experiment. The marked decrease in $\mathrm{T}^{\mathbf{c}} \mathrm{H}_{2} \mathrm{O}$ at each level of solute excretion on a low protein diet as compared to the control diet evidently cannot be explained by changes in GFR in this case. At each level of solute excretion, the urea concentration of the urine is higher on the regular than on the low protein diet. This was true in the experiments in all five dogs.

\section{Acute effect of urea on urine concentration}

The acute effect of urea on maximum urine concentration was tested in seven experiments in
TABLE IV

Acute effect of urea on urine concentration in man on low protein diet

\begin{tabular}{|c|c|c|c|}
\hline Time & $\begin{array}{l}\text { Urine } \\
\text { flow }\end{array}$ & $\begin{array}{c}\text { Urine } \\
\text { osmolality }\end{array}$ & $\begin{array}{l}\text { Urea } \\
\text { concen- } \\
\text { tration }\end{array}$ \\
\hline $\begin{array}{c}\min . \\
0-60 \\
60-120 \\
120-180\end{array}$ & $\begin{array}{c}\text { ml. } / \min . \\
0.30 \\
0.31 \\
0.33\end{array}$ & $\begin{array}{c}\text { mOsm. } / \mathrm{Kg} . \mathrm{H}_{2} \mathrm{O} \\
753 \\
751 \\
775\end{array}$ & $\begin{array}{c}\mu M / \mathrm{ml} . \\
303 \\
265\end{array}$ \\
\hline 210 & \multicolumn{3}{|c|}{$10 \mathrm{Gm}$. urea in $c a .30 \mathrm{ml} . \mathrm{H}_{2} \mathrm{O}$ P.O. } \\
\hline $\begin{array}{l}180-240 \\
240-300 \\
300-360 \\
360-420 \\
420-480 \\
480-540\end{array}$ & $\begin{array}{l}0.38 \\
0.55 \\
0.63 \\
0.45 \\
0.47 \\
0.40\end{array}$ & $\begin{array}{r}834 \\
914 \\
963 \\
1,047 \\
1,054 \\
1,047\end{array}$ & $\begin{array}{l}489 \\
517 \\
601\end{array}$ \\
\hline
\end{tabular}

four dogs which had been on the low protein diet for 8 to 20 days. Table III shows one such experiment. An abrupt increase in urine concentration followed the administration of a small dose of urea in spite of a concurrent rise in solute excretion. Some 80 per cent of the increase in urine osmolality can be accounted for by the increased urinary urea concentration. In four other experiments in which urine osmolality increased sharply, about 75 to 90 per cent of the increase could be accounted for by an increased urea concentration. At least one experiment in which urine osmolality rose sharply was obtained in each dog studied. In experiments in two of these same dogs, a dose of urea higher than that which produced the abrupt rise in osmolality was given. Urine concentration remained constant or fell slightly, while solute excretion increased three- to sevenfold.

In Table IV, one of three similar experiments in man is shown. As in the dog, a rise in urine concentration in spite of an increase in solute excretion follows oral administration of urea. In the three experiments in humans, rises in urine urea

TABLE V

Kidney tissue analysis in dog on low protein diet

\begin{tabular}{|c|c|c|c|c|c|}
\hline & Urea & Sodium & Potassium & Chloride & Water \\
\hline $\begin{array}{l}\text { Cortex } \\
\text { Outer medulla } \\
\text { Inner medulla } \\
\text { Papilla } \\
\text { Urine }\end{array}$ & $\begin{array}{c}\mu M / G m . H_{2} \mathrm{O} \\
7 \\
55 \\
66 \\
64\end{array}$ & $\begin{array}{c}\mu E q . / \mathrm{Gm} . \mathrm{H}_{2} \mathrm{O} \\
108 \\
197 \\
250 \\
282 \\
95\end{array}$ & $\begin{array}{c}\mu E q . / \mathrm{Gm} . \mathrm{H}_{2} \mathrm{O} \\
71 \\
72 \\
47 \\
51 \\
51\end{array}$ & $\begin{array}{c}\mu E q . / \mathrm{Gm} . \mathrm{H}_{2} \mathrm{O} \\
103 \\
180 \\
223 \\
236\end{array}$ & $\begin{array}{c}\text { \% wet wt. } \\
81.7 \\
81.0 \\
84.6 \\
83.4\end{array}$ \\
\hline
\end{tabular}

Urine flow, $0.10 \mathrm{ml}$. per minute; osmolality, $544 \mathrm{mOsm}$. per $\mathrm{Kg} . \mathrm{H}_{2} \mathrm{O}$ 
UREA AND URINE CONCENTRATION

TABLE VI

Kidney analysis in dehydrated dogs on regular diet

\begin{tabular}{|c|c|c|c|c|c|}
\hline & Urea & Sodium & Potassium & Chloride & Water \\
\hline \multirow[b]{2}{*}{$\begin{array}{l}\text { Cortex } \\
\text { Outer medulla } \\
\text { Inner medulla } \\
\text { Papilla } \\
\text { Urine }\end{array}$} & $\begin{array}{c}\mu M / G m . H_{2} O \\
\text { Urine osm }\end{array}$ & $\begin{array}{c}\mu E q . / G m . H_{2} O \\
\text { ty, } 1,061 \mathrm{mOsn}\end{array}$ & $\begin{array}{l}\mu E_{q} / \mathrm{Gm} . \mathrm{H}_{2} \mathrm{O} \\
\text { per } \mathrm{Kg} \cdot \mathrm{H}_{2} \mathrm{O}\end{array}$ & $\mu E q . / G m . H_{q} O$ & $\%$ wet wt. \\
\hline & $\begin{array}{r}9 \\
167 \\
476 \\
647\end{array}$ & $\begin{array}{r}94 \\
161 \\
248 \\
284 \\
63\end{array}$ & $\begin{array}{r}76 \\
76 \\
38 \\
44 \\
102\end{array}$ & $\begin{array}{r}74 \\
132 \\
225 \\
242\end{array}$ & $\begin{array}{l}78.0 \\
77.0 \\
83.0 \\
78.9\end{array}$ \\
\hline \multicolumn{6}{|c|}{ Urine osmolality, 1,794 mOsm. per $\mathrm{Kg} \cdot \mathrm{H}_{2} \mathrm{O}$} \\
\hline $\begin{array}{l}\text { Cortex } \\
\text { Outer medulla } \\
\text { Inner medulla } \\
\text { Papilla } \\
\text { Urine }\end{array}$ & $\begin{array}{r}25 \\
408 \\
780 \\
1,184\end{array}$ & $\begin{array}{r}99 \\
168 \\
278 \\
317 \\
73\end{array}$ & $\begin{array}{r}77 \\
71 \\
43 \\
45 \\
134\end{array}$ & $\begin{array}{r}89 \\
149 \\
264 \\
281\end{array}$ & $\begin{array}{l}76.1 \\
77.5 \\
81.9 \\
76.6\end{array}$ \\
\hline
\end{tabular}

accounted for some 90 to 110 per cent of the increase in urine osmolality.

\section{Kidney tissue analysis}

The kidneys of each dog studied on the low protein diet were analyzed for sodium, potassium, chloride and urea. The dogs had been on the diet for 10 to 30 days when the analyses were made. Table V shows the complete analysis for one dog. In Figure 2, the urine urea and tissue urea and sodium concentrations of all the dogs on the low protein diet are represented by solid symbols.
For purposes of comparison, complete kidney analyses in two dogs on a regular diet are presented in Table VI, and data from 19 such dogs are shown by the open symbols in Figure 2. Sodium, potassium and chloride concentrations in the kidneys of the dogs on low protein diets were within the range for these elements found in dehydrated dogs on regular diets. The average sodium concentration in the papilla of the five dogs, studied after 42 hours dehydration, was $300 \pm$ $24 \mu \mathrm{Eq}$. per $\mathrm{Gm}$. tissue water (mean \pm S.E. mean). In six dogs on the regular diet, dehy-

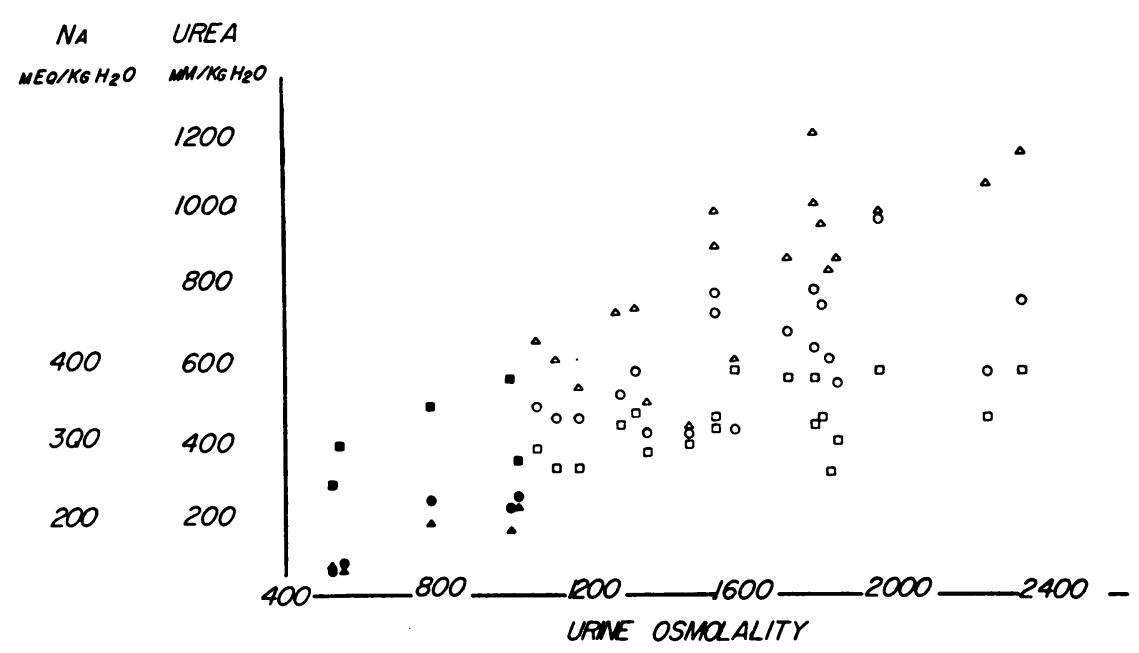

Fig. 2. Kidney Analyses in Dogs on Regular Diet (Open Symbols) and Low Protein Diet (Solm Symbols)

The squares represent the sodium concentration ( $\mu$ Eq. per $\mathrm{Gm} . \mathrm{H}_{2} \mathrm{O}$ ) ; the circles, urea concentration ( $\mu \mathrm{M}$ per $\mathrm{Gm} . \mathrm{H}_{2} \mathrm{O}$ ) in the tissue water of the papilla. The triangles represent urine urea concentration ( $\mu \mathrm{M}$ per $\mathrm{ml}$.) in the urine collected just prior to sacrifice. The abscissa shows the osmolality of this urine ( $\mathrm{mOsm}$. per $\mathrm{Kg}$. $\mathrm{H}_{2} \mathrm{O}$ ). 
drated 40 to 48 hours, papillary sodium was $300 \pm$ $13 \mu \mathrm{Eq}$. per $\mathrm{Gm}$. tissue water.

The concentration of urea in the tissue water of the papilla was approximately equal to or slightly greater than the urinary urea concentration in each dog studied on a low protein diet. The values ranged from 50 to $250 \mu \mathrm{M}$ per $\mathrm{Gm}$. tissue water. In each case, urine flow just prior to sacrifice was $0.2 \mathrm{ml}$. per minute or less, and in three dogs it was $0.08 \mathrm{ml}$. per minute or less. In the latter dogs, the disparity between papillary and urinary urea concentration was most marked.

\section{DISCUSSION}

In experiments in which rats were fed a variety of substances separately or in mixtures, Gamble, McKhann, Butler and Tuthill (1) found that the water requirements for urinary excretion of mixed solute loads were additive except when urea was a component of the mixture. When urea was present in a mixture, urine volume was much less than the sum of the requirements for urea and the other solutes as determined separately. These results led to the conclusion that "there is an economy of water in the secretion of urine referable to urea." Although these experiments have been criticized because water intake was not controlled, more recent work indicates that the conclusions are nevertheless essentially correct. Kellogg and Koike (2) found that the negative free-water clearance at all levels of solute excretion was much higher in rats during urea infusion than during the infusion of a variety of other solutes. Radford (3) found that urine osmolality in rats is higher when urea as compared to sodium chloride is added to the diet. A marked decrease in the water requirement for excretion of a solute load when urea was added to the diet was observed in rats by Crawford (4). In man, the experiments of Epstein, Kleeman, Pursel and Hendrikx (5) showed that urine concentrating ability is decreased on a low-protein diet.

All these studies, as well as those presented in this paper, lead to the conclusion that urea has a unique role in the concentrating mechanism. In the preceding paper (6) and elsewhere (7), an hypothesis has been presented which accounts for this role of urea. It is postulated that the passive accumulation of urea in the medullary interstitial fluid from the collecting ducts permits urea to add to the osmotic pressure of the urine without being balanced by an equivalent amount of sodium chloride actively transported into the medullary interstitium. The data in this paper confirm several predictions derived from this hypothesis.

In an animal on a low protein diet, the filtered load of urea is decreased. The amount of urea reaching the collecting ducts is presumably also greatly diminished. If accumulation of urea from the ducts in the medullary interstitium enhances urine concentration, maximum urine osmolality would be expected to fall when a low protein diet is given. The magnitude of the fall in urine osmolality due to changes in medullary urea should be approximately equal to the change in urinary urea concentrations. In these studies on the dog, the decrease in urine urea concentration accounts for some 80 per cent of the decrease in urine osmolality. Because of the change in osmolality and urea concentration as urine passes through the ureters and bladder at low flows (10) [also see footnote to Results in preceding paper (6)], it is difficult to be certain whether the change in urine urea concentrations in the kidney actually accounts for the entire change in urine osmolality on the low protein diet in the dog, or whether other factors must be considered. In man (5), the urine flows remained much higher and the decrease in urine urea concentration accounted for a large fraction of the decrease in osmolality in all but two subjects, in whom only small decreases in urinary urea concentration occurred.

If the decrease in urine osmolality on a low protein diet is in large part due to the fall in urinary urea, one would predict that maximum urine concentration would increase abruptly when urea is given to an animal on a low protein diet. The data in Tables III and IV show that this is true in both the dog and in man. The increase in urinary urea concentration accounts for the greatest part of the increased urinary osmolality. In the human studies, agreement between changes in urea concentration and osmolality was so close as to require no other factors to be postulated to account for the change. In the dog, the change in urea apparently accounts for about 80 per cent of the increase in osmolality. Because of the changes in urine composition in the lower urinary tract mentioned above, it is difficult to be sure how close 
the agreement actually is between the changes in urea and the osmolality of urine as it left the kidney. In the studies of Epstein and co-workers (5), urea was found to have a chronic but not an acute effect on urine concentration in humans on low protein diets. In the experiment illustrated, urine osmolality remained constant in the face of a twofold increase in solute excretion, which with other solutes would be expected to result in a fall in urine osmolality. The acute dose of urea was about three times that given in the present experiments. Probably the effects of a somewhat greater solute diuresis in the studies of Epstein and associates (5) masked the rise in urine concentration which otherwise would have occurred.

The maximum negative free-water clearance falls in dogs and man (5) on low protein diets. However, it is difficult to interpret and to quantify the changes in dogs reported in the present studies. In these experiments, and in a number of other unpublished studies done in dogs on regular diets for various purposes, $\mathrm{T}^{\mathbf{c}_{\mathrm{H}_{2} \mathrm{O}}}$ did not regularly approach a maximum as solute excretion was increased by mannitol infusions. Instead, $\mathrm{T}^{\mathbf{c}} \mathrm{H}_{2} \mathrm{O}$ usually first increased, then decreased as solute excretion was raised. ${ }^{1}$ It was therefore not possible to determine whether urea has an acute effect on $\mathrm{T}_{\mathrm{H}_{2} \mathrm{O}}$. The present hypothesis would predict that the $\mathrm{T}_{\mathrm{H}_{2} \mathrm{O}}$ would be greater during mannitol diuresis on a regular diet, to the extent

\footnotetext{
1 Positive free-water clearances (urine hypotonic to plasma) were common, even in dehydrated dogs receiving large doses of vasopressin, when the excreted solute was 10 to 15 per cent or more of the filtered solute. At low solute excretions, the tubular fluid becomes isosmotic with plasma in the distal convoluted tubule, when antidiuretic hormone is present (11). The finding that urine is dilute to plasma at moderately high solute loads presumably indicates incomplete osmotic equilibration of tubular fluid in the distal convoluted tubule. The observed $\mathrm{T}^{\mathrm{c}}{ }_{\mathrm{H}_{2} \mathrm{O}}$ at moderate and high solute loads in these dogs thus probably represents the difference between the "positive free-water" present at the end of the distal convoluted tubule and the net reabsorption of free-water ("negative free-water") at the concentrating site in the collecting ducts. Only if the degree of residual disequilibrium at the end of the convoluted tubule is the same in the dog on high and low protein diets is the appearance of net "positive free-water" at lower solute excretions in the dog on a low protein diet an indication of the decrease in net water reabsorption at the concentrating site.
}

that urine urea concentrations are greater. The data in Table II show that at comparable levels of solute excretion urea concentrations are higher on a regular diet than on a low protein diet. A small increase in urine urea concentration (balanced by urea in the interstitial fluid of the medulla) would substantially increase $\mathrm{T}^{\mathrm{c}}{ }_{\mathrm{H}_{2} \mathrm{O}}$ at high flows. For example, if $50 \mu \mathrm{M}$ per $\mathrm{ml}$. of urea were added when urine flow is $8 \mathrm{ml}$. per minute and $\mathrm{T}^{\mathrm{c}} \mathrm{H}_{2} \mathrm{O}$ is $2 \mathrm{ml}$. per minute $\mathrm{T}^{\mathrm{c}} \mathrm{H}_{2} \mathrm{O}$ would increase to about $3.3 \mathrm{ml}$. per minute. In two dogs it was found that during infusion of urea the negative free-water clearance is higher at all levels of solute excretion than that found during mannitol infusion. This was true both on high and on low protein diets. (However, the increase in $\mathrm{T}^{\mathbf{c}} \mathbf{H}_{2} \mathrm{O}$ was in proportion to the increase in GFR which regularly occurs when urea is given as compared to mannitol.) In man (5), no acute effect of urea on $\mathrm{T}^{\mathbf{c}}{ }_{\mathrm{H}_{2} \mathrm{O}}$ was found.

If urea accumulates in the medulla by passive movement from the collecting ducts, the concentration of urea in medullary tissue water cannot be greater than that in the urine. In the dogs on low protein diets, the urea concentration in the tissue water for the papilla was equal to or somewhat greater than that of the urine. However, as was discussed above and in the preceding paper (6), urine urea concentrations decrease up to 40 per cent when urine is perfused through the ureter and bladder at flows comparable to those seen in dehydrated dogs on low protein diets. This factor probably accounts for the greater tissue than urine concentrations in these dogs. SchmidtNielsen (12) has postulated that urea is actively transported in a counter-current multiplier mechanism in the medulla. In our opinion all the data in the dog can be explained without invoking active movement of urea. In addition, the explanation of the low medullary urea concentrations during water diuresis [(13) and unpublished observations] in the presence of an active transport mechanism requires either that the activity of the mechanism be graded according to urine flow, or that the flow take place through wholly cortical nephrons and capillaries in water diuresis (11). A much simpler explanation, requiring no ad hoc hypotheses, is that tissue urea concentration is low because the urine urea concentration is low. According to the hypothesis of passive accumu- 
lation of urea, the urea concentration in the medulla cannot exceed that in the urine.

In the preceding paper, it was shown that acute changes in glomerular filtration rate under certain circumstances are associated with a fall in urine concentration. Most of this decrease could be explained as due to a decrease in delivery of urea to the medulla. This part of the fall in osmolality would be analogous to the falls reported in this paper on low protein diets, though the ultimate cause of decreased delivery of urea to the medulla is, of course, quite different. In addition, a decrease in sodium concentration in the medulla was sometimes found during acute reduction of the GFR at low solute excretions. A chronic reduction of GFR occurred in most of the dogs maintained on a low protein diet. However, the sodium concentrations in the medulla (Table V) are within the range usually seen in dehydrated dogs on regular diets in our studies. At least by this rather gross measure, active sodium transport into the medullary interstitial fluid does not seem to be decreased on a low protein diet.

The data in this paper are consistent with the hypothesis that the "economy of water in renal function referable to urea" (1) is the result of the passive accumulation of urea in the medullary interstitial fluid. Such an economy is a particularly favorable adaptation, since in mammals urea is the principal waste product requiring water for excretion in the urine.

\section{SUM MARY}

1. The maximum urine osmolality and the maximum negative free-water clearance are reduced in dogs on low protein diets. Eighty per cent or more of the decrease in osmolality can be accounted for by the decrease in the urea concentration of the urine.

2. In both the dog and man, the administration of urea to individuals on a low protein diet results in an abrupt increase in maximum urine osmolality. Eighty per cent or more of this increase in the dog, and essentially all of the increase in man, can be accounted for by the increased urea concentration in the urine.
3. Renal medullary tissue urea concentration in the dog on a low protein diet is markedly reduced, but tissue sodium concentration is unchanged.

4. These observations support the hypothesis that the passive accumulation of urea in the medullary interstitial fluid increases the maximum urine concentrations which the kidney can attain, and that urea therefore has a unique role in the urine concentrating mechanism.

\section{REFERENCES}

1. Gamble, J. L., McKhann, C. F., Butler, A. M., and Tuthill, E. An economy of water in renal function referable to urea. Amer. J. Physiol. 1934, 109, 139.

2. Kellogg, R. H., and Koike, T. I. Difference between mannitol and urea diuresis in the rat (abstract). Amer. J. Physiol. 1955, 183, 633.

3. Radford, E. P., Jr. Factors modifying renal concentrating mechanism in rats. Fed. Proc. 1958, $17,127$.

4. Crawford, J. D., Doyle, A. P., and Probst, J. H. Service of urea in renal water conservation. Amer. J. Physiol. In press.

5. Epstein, F. H., Kleeman, C. R., Pursel, S., and Hendrikx, A. The effect of feeding protein and urea on the renal concentrating process. J. clin. Invest. 1957, 36, 635.

6. Levinsky, N. G., Davidson, D. G., and Berliner, R. W. Effects of reduced glomerular filtration on urine concentration in the presence of antidiuretic hormone. J. clin. Invest. 1959, 38, 730.

7. Berliner, R. W., Levinsky, N. G., Davidson, D. G., and Eden, $M$. Dilution and concentration of the urine and the action of antidiuretic hormone. Amer. J. Med. 1958, 24, 730.

8. Berliner, R. W., and Davidson, D. G. Production of hypertonic urine in the absence of pituitary antidiuretic hormone. J. clin. Invest. 1957, 36, 1416.

9. Smith, H. W. Principles of Renal Physiology. New York, Oxford University Press, 1956, p. 121.

10. Levinsky, N. G., and Berliner, R. W. Amer. J. Physiol. In press.

11. Wirz, H. The location of antidiuretic action in the mammalian kidney in The Neurohypophysis, $\mathrm{H}$. Heller, Ed. New York, Academic Press Inc., 1957, p. 157.

12. Schmidt-Nielsen, B. Urea excretion in mammals. Physiol. Rev. 1958, 38, 139.

13. Ullrich, K. J., and Jarausch, K. H. Untersuchungen zum Problem der Harnkonzentrierung und Harnverdünnung. Pflüg. Arch. ges. Physiol. 1956, 262, 537. 